DOI 10.18551/rjoas.2021-10.14

\title{
THE ROLE OF TRADITIONAL MARKETS IN INCREASING INTEREST IN ENTREPRENEURSHIP AND THE ECONOMY OF THE COMMUNITY IN THE MIDDLE OF BALI TOURISM DOWN: A CASE STUDY ON BADUNG MARKET
}

\author{
I Gede Surya Pratama*, Ida Ayu Agung Idawati, Ni Made Rustini \\ Faculty of Economics and Business, University of Warmadewa, Denpasar, Indonesia \\ *E-mail: igedesuryapratama@gmail.com
}

\begin{abstract}
The outbreak of the corona virus has had a major impact on the current condition of Bali. Bali, which is the basis of tourism activities, began to decline and weakens, there were many mass layoffs and hotels closed or went out of business. The decline in tourism resulted in the community experiencing a considerable impact in terms of finances, especially income which began to decline. There are some people who start to make a business because they see the traditional market is still crowded. Even when conditions are difficult, like now, the market is still open and the transaction process is still happening in the market, compared to shops and malls that have to follow the rules for closing stores during the pandemic. So that the traditional market is considered capable of turning the remaining money to meet the needs of life. The purpose of this study is to determine the role of traditional markets in increasing people's income and interest in entrepreneurship in the midst of the decline of Bali tourism. This study uses 65 market participants and also the surrounding community. The results of this study indicate that there is a significant influence between the role of the traditional market (Badung Market) on the interest in entrepreneurship and people's income.
\end{abstract}

\section{KEY WORDS}

Traditional markets, entrepreneurial interests, community, economy.

The tourism sector has great correlations and various potentials in supporting the productive economic sector. From the point of view of the national economy, the tourism sector is seen as a buffer for the non-oil and gas sector, with priority activities that are directed to be the mainstay sector in foreign exchange earnings, encourage development and regional income and improve people's welfare, namely in contributing to the income of the community around tourism objects. With the presence of tourism, the community's economy grows, such as the opening of job opportunities, the development of the business world, including the level of community welfare (Putri and Amelia, 2019).

The island of Bali is an island that has a variety of tourist attractions that are well known throughout the country. The variety of attractions presented on the island of Bali such as nature, art and culture, culinary, agriculture, and even the friendliness of the local people are able to attract tourists to come and vacation on the island of Bali. However, according to data collected by the Central Statistics Agency for the Province of Bali, foreign tourists visiting the island of Bali have decreased from the end of 2019 to the present at the end of 2020.

The outbreak of the corona virus has had a major impact on the current condition of Bali. Bali, which is the basis of tourism activities, began to weaken, there were many mass layoffs and hotels closed or went out of business. The decline in tourism resulted in the community experiencing a considerable impact in terms of finance. There are some people who start to make a business because they see the traditional market is still crowded. Even when conditions are difficult, like now, the market is still open and the transaction process is still happening in the market, compared to shops and malls that have to follow the rules for closing stores during the pandemic. So that the traditional market is considered capable of turning the remaining money to meet the needs of life.

Maintaining current financial conditions, seeing from the market which is always active, many people change professions to become traders because they are considered the right 
job to do at this time to increase income. The community began to sell their garden products and livestock products in order to survive in the current conditions in the market. The suppliers who usually send their goods to the hotel have also started bringing their goods to the market.

Traditional markets are places where sellers and buyers meet and are marked by transactions between sellers and buyers directly and there is a bargaining process, the building usually consists of stalls or outlets, booths and open grounds opened by the seller or a market manager, Hardiati (2019). Most sell daily necessities such as food ingredients in the form of fish, fruit, vegetables, eggs, meat, cloth, clothing, services and others.

The creation of an entrepreneurial field is also found in the market. For now, the market has become an inherent part of social life; the market is used as a forum for entrepreneurship and increasing income. Some people even depend on the market for their daily work, Hardiati (2019). Therefore, the existence of the market is very vital for society as well as for the economy. In daily activities, the market can be interpreted as a meeting place for buyers and sellers. However, in the economic field, the market is not defined as a place, but rather prioritizes buying and selling activities. Not only that, the market is also a supporter of increasing regional revenue budgets. So that the existence of markets in the community is very much needed, both traditional markets and modern markets.

H1: The Role of Traditional Markets Affects Community Entrepreneurial Interest;

H2: The Role of Traditional Markets Influence on Increasing People's Income.

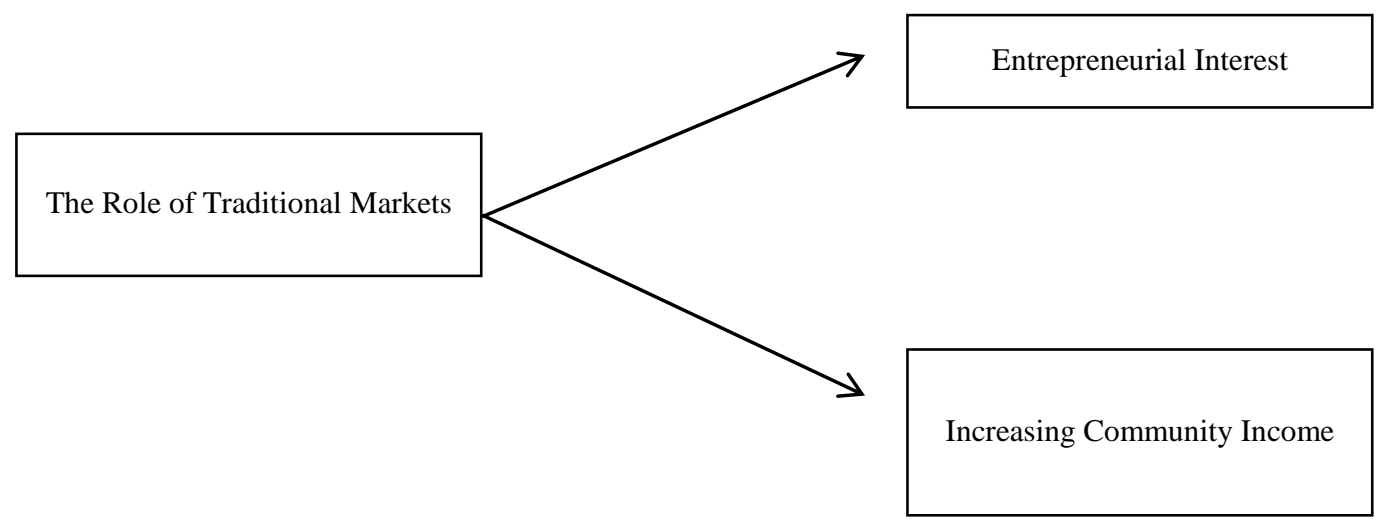

Figure 1 - Framework of Thought

The term market denotes a place where sellers and buyers gather to exchange their goods, for example in the squares, Abdullah and Tantri (2014). In economics, the understanding of the market does not have to be associated with a place called the market in the everyday sense. A market in economics is anywhere a transaction occurs between a seller and a buyer (Boediono, 2015).

According to Slameto (2015: 180), interest is a sense of preference and a sense of interest in a thing or activity, without anyone telling. Interest is basically the acceptance of a relationship between one and something outside oneself. The stronger or closer the relationship, the greater the interest. According to Octavionica (2016:13), entrepreneurship is the drive and desire to create a creative and innovative business or business with the aim of having a business or business that can create jobs and change the economy. So the interest in entrepreneurship is a feeling or desire to encourage someone to create a business or business to change the economy

\section{METHODS OF RESEARCH}

The data collection used in this study used a survey method through a questionnaire. The data that has been collected will be processed using partial least squares (PLS) analysis. The research was conducted at the Traditional Market (Badung Market) because it 
is the largest market and the busiest buying and selling activity in Bali. The population in this study is the entire community in Badung Market and around Badung Market. The sample is part of the total population owned by the population by using the sampling technique. The sampling technique in this study is accidental sampling. The number of samples is 13 questions $\times 5=65$, so the research sample used is 65 samples. The variable measurement scale uses a 5-point Likert scale.

The data analysis technique used in this study is Structural Equation Modeling Analysis based on Partial Least Square with the smartPLS 3.0 program.

The measurement model (outer model) was used to test the construct validity and instrument reliability. The following is the result of the schematic model of the PLS program that was tested:

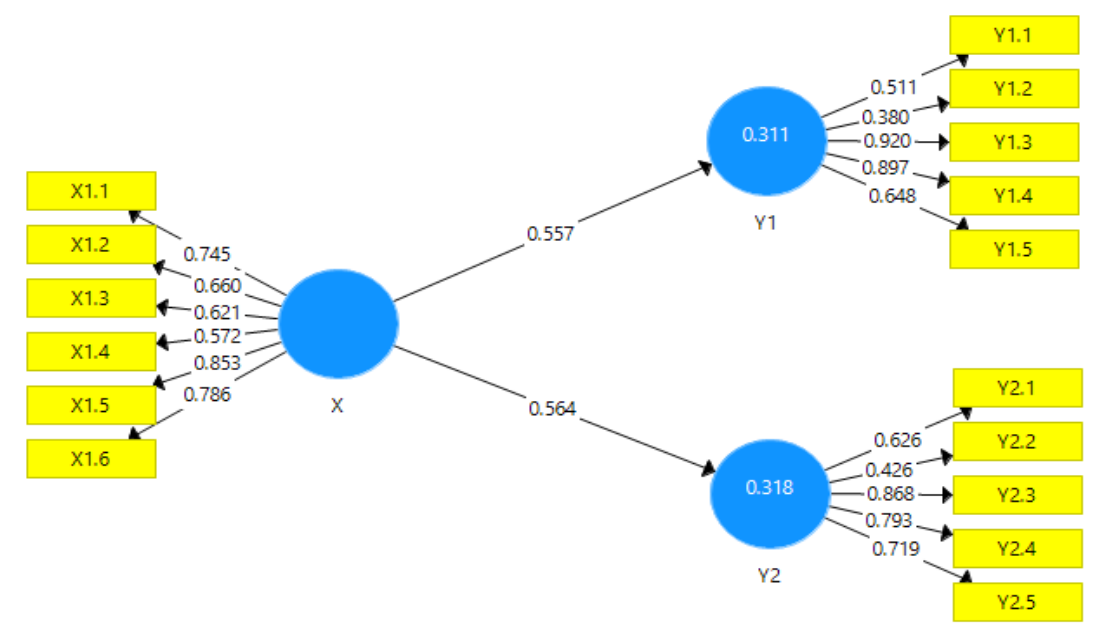

Figure 2 - Outer Model

To test convergent validity, the outer loading value or loading factor is used. An indicator is declared to meet convergent validity in the good category if the outer loading value is $>0.7$. The following is the value of the outer loading of each indicator on the research variable:

Table 1 - Outer Loading

\begin{tabular}{|c|c|c|}
\hline Variable & Indicator & OuterLoading \\
\hline \multirow{6}{*}{$\begin{array}{l}\text { The Role of Traditional Markets } \\
\qquad(\mathrm{X})\end{array}$} & $\mathrm{X} 1.1$ & 0.745 \\
\hline & $\mathrm{X} 1.2$ & 0.660 \\
\hline & $\mathrm{X} 1.3$ & 0.621 \\
\hline & $\mathrm{X} 1.4$ & 0.572 \\
\hline & $\mathrm{X} 1.5$ & 0.853 \\
\hline & $\mathrm{X} 1.6$ & 0.786 \\
\hline \multirow{5}{*}{$\begin{array}{l}\text { Entrepreneurial Interest } \\
\qquad(\mathrm{Y} 1)\end{array}$} & $\mathrm{Y} 1.1$ & 0.511 \\
\hline & Y1.2 & 0.380 \\
\hline & Y1.3 & 0.920 \\
\hline & Y1.4 & 0.897 \\
\hline & Y1.5 & 0.648 \\
\hline \multirow{5}{*}{$\begin{array}{l}\text { Communitylncome } \\
\text { (Y2) }\end{array}$} & Y2.1 & 0.626 \\
\hline & Y2.2 & 0.426 \\
\hline & Y2.3 & 0.868 \\
\hline & Y2.4 & 0.793 \\
\hline & Y2.5 & 0.719 \\
\hline
\end{tabular}

Source: SmartPLS 3 Results, 2021.

Based on table 1 of the data above, it is known that each indicator of the research variable has a value of outer loading $>0.7$. However, there are still some indicators that have an outer loading value. According to Chin as quoted by Imam Ghozali, the outer loading value between $0.5-0.6$ is considered sufficient to meet the convergent validity requirements (Ghozali, 2014). The data above shows that there are still variable indicators whose outer 
loading values are below 0.5 , namely the indicator of interest in doing business (Y1.2 = $0.380)$ and the indicator of community income (Y2.2 $=0.426)$.

In addition to seeing the value of outer loading, to test the validity can be seen from the results of the discriminant validity test. The discriminant validity test uses the cross loading value. An indicator is declared to meet discriminant validity if the value of the cross loading indicator on the variable is the largest compared to other variables (Ghozali, 2014).

Based on table 2 which will be presented on the next page, it can be seen that each indicator in the research variable has the largest cross loading value on the variable it forms compared to the cross loading value on other variables. So that all indicators are declared feasible or valid to be used in research and can be analyzed further.

Table 2 - Cross Loading

\begin{tabular}{|c|c|c|c|}
\hline \multirow[b]{2}{*}{ Indicator } & \multicolumn{3}{|c|}{ Variable } \\
\hline & $\begin{array}{l}\text { The Role of Traditional Markets } \\
(X)\end{array}$ & $\begin{array}{c}\text { Entrepreneurial Interest } \\
(\mathrm{Y} 1)\end{array}$ & $\begin{array}{l}\text { Communitylncome } \\
\text { (Y2) }\end{array}$ \\
\hline $\mathrm{X} 1.1$ & 0.745 & 0.343 & 0.339 \\
\hline $\mathrm{X} 1.2$ & 0.660 & 0.224 & 0.182 \\
\hline $\mathrm{X} 1.3$ & 0.621 & 0.227 & 0.349 \\
\hline X1.4 & 0.572 & 0.280 & 0.293 \\
\hline $\mathrm{X} 1.5$ & 0.853 & 0.599 & 0.610 \\
\hline X1.6 & 0.786 & 0.490 & 0.435 \\
\hline Y1.1 & 0.197 & 0.511 & 0.387 \\
\hline Y1.2 & 0.180 & 0.380 & 0.276 \\
\hline Y1.3 & 0.563 & 0.920 & 0.455 \\
\hline Y1.4 & 0.545 & 0.897 & 0.493 \\
\hline Y1.5 & 0.230 & 0.648 & 0.331 \\
\hline Y2.1 & 0.297 & 0.326 & 0.626 \\
\hline Y2.2 & 0.314 & 0.293 & 0.426 \\
\hline Y2.3 & 0.493 & 0.523 & 0.868 \\
\hline Y2.4 & 0.453 & 0.406 & 0.793 \\
\hline Y2.5 & 0.378 & 0.333 & 0.719 \\
\hline
\end{tabular}

Source: SmartPLS 3 Results, 2021.

Composite Reliability is the part that is used to test the reliability value of the indicators on a variable. A variable can be declared to meet composite reliability if it has a composite reliability value $>0.6$. The following is the composite reliability value of each variable used in this study:

Table 3 - Composite Reliability

\begin{tabular}{|c|c|}
\hline Variable & CompositeReliability \\
\hline The Role of Traditional Markets $(\mathrm{X})$ & 0.859 \\
\hline Interest in Entrepreneurship $(\mathrm{Y} 1)$ & 0.817 \\
\hline Communitylncome (Y2) & 0.823 \\
\hline
\end{tabular}

Source: SmartPLS 3 Results, 2021.

Based on the data in table 3 above, it can be seen that the composite reliability value of all research variables is $>0.6$. These results indicate that each variable has met composite reliability so that it can be concluded that all variables have a high level of reliability.

The reliability test with composite reliability can be strengthened by using the Cronbach's Alpha value. A variable can be declared reliable or fulfills Cronbach's Alpha if it has a Cronbach's Alpha value $>0.7$ (Eisingerich and Ruberu, 2010). Here are the Cronbach's Alpha values for each variable:

Table 4 - Cronbach's Alpha

\begin{tabular}{|c|c|}
\hline Variable & Cronbach's Alpha \\
\hline The Role of Traditional Markets (X) & 0.809 \\
\hline Interest in Entrepreneurship (Y1) & 0.735 \\
\hline Communitylncome (Y2) & 0.726 \\
\hline
\end{tabular}

Source: SmartPLS 3 Results, 2021. 
Based on the data in table 4 above, it can be seen that the Cronbach's Alpha value of each research variable is $>0.7$. These results indicate that each research variable has met the requirements of the Cronbach's Alpha value, so it can be concluded that all variables have a high level of reliability.

The structural model in PLS is evaluated using R2 for the dependent variable and the path coefficient value for the independent variable which is then assessed for significance based on the t-statistic value of each path. The structural model of this research can be seen in the following figure:

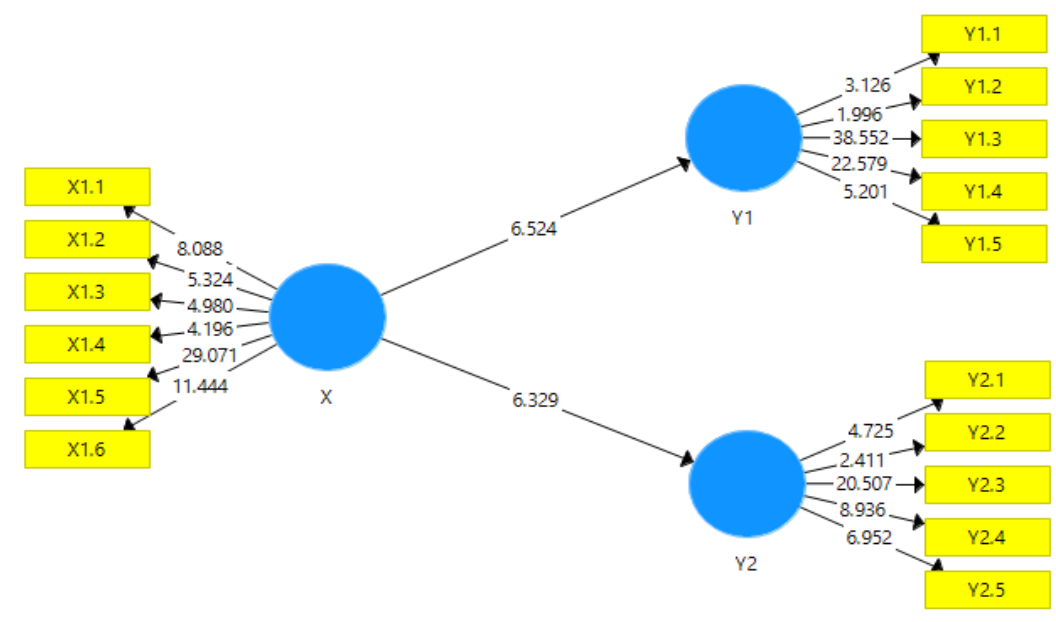

Figure 3 - Inner Model

Path coefficient evaluation is used to show how strong the effect or influence of the independent variable on the dependent variable. While the coefficient determination (RSquare) is used to measure how much the endogenous variables are influenced by other variables. Chin said the results of $\mathrm{R} 2$ of 0.67 and above for endogenous latent variables in the structural model indicate the effect of exogenous variables (which affect) on endogenous variables (which are influenced) is included in the good category. Meanwhile, if the result is $0.33-0.67$ then it is included in the medium category, and if the result is $0.19-0.33$ then it is included in the weak category (Ghozali, 2014). The following table shows the path coefficient results obtained from the SmartPLS output:

Table 5 - Path Coefficients

\begin{tabular}{|c|c|c|c|c|}
\hline & Original Sample Estimate & Mean of Sub samples & Standard Deviation & T-Statistic \\
\hline $\mathrm{X} 1 \rightarrow \mathrm{Y} 1$ & 0.557 & 0.590 & 0.085 & 6,524 \\
\hline $\mathrm{X} 1 \rightarrow \mathrm{Y} 2$ & 0.564 & 0.591 & 0.089 & 6329 \\
\hline
\end{tabular}

Source: SmartPLS 3 Results, 2021.

Based on the data in table 5 above, it can be seen that the path coefficient value of the role of traditional markets on entrepreneurial interest is 6.524 . The path coefficient value for the role of traditional markets in the community's economy is 6,329. These results indicate that all variables in this model have path coefficient values with positive numbers. The greater the value of the path coefficient on one independent variable to the dependent variable, the stronger the influence between the independent variables on the dependent variable. Based on the data processing that has been done using the SmartPLS 3.0 program, the R-Square values are obtained as follows:

Table 6 - R-Square Value

\begin{tabular}{|c|c|}
\hline Variable & R-Square Nilai Value \\
\hline Interest in Entrepreneurship (Y1) & 0.311 \\
\hline Communitylncome (Y2) & 0.318 \\
\hline
\end{tabular}

Source: SmartPLS 3 Results, 2021. 
Based on the data in table 6 , it can be seen that the R-Square value for the performance variable is 0.311 . Obtaining this value explains that the percentage of interest in entrepreneurship can be explained by the role of traditional markets of $31.1 \%$. For the RSquare value obtained by the community income variable is 0.318 . Obtaining this value explains that the percentage of people's income can be explained by the role of traditional markets of $31.8 \%$.

The goodness of fit assessment is known from the Q-Square value. The Q-Square value has the same meaning as the coefficient of determination (R-Square) in the regression analysis, where the higher the Q-Square, the model can be said to be better or more fit with the data. The results of the calculation of the $\mathrm{Q}$-Square value are as follows:

$$
\text { Q-Square }=1-[(1-\mathrm{R} 21) \times(1-\mathrm{R} 22)]=0.530
$$

Based on the results of the calculations above, the Q-Square value is 0.530 . This shows that the diversity of the research data described by the research model is 53 percent. While the remaining 47 percent is explained by other factors that are outside this research model. These results state that this research model has a good goodness of fit.

Hypothesis test. Hypothesis testing in this study was conducted by looking at the results of the T-Statistic and P-Values values. The research hypothesis can be declared accepted if the P-Values $<0.05$ (Yamin and Kurniawan, 2011). The following are the results of hypothesis testing obtained in this study through the inner model:

Table 7 - T-Statistics and P-Values

\begin{tabular}{|c|l|c|c|c|}
\hline Hypothesis & Influence & T-Statistic & $P$-Values & Results \\
\hline H1 & The role of traditional markets $\rightarrow$ interest in entrepreneurship & 6,524 & 0.000 & Accepted \\
\hline H2 & The role of traditional markets $\rightarrow$ community economy & 6329 & 0.000 & Accepted \\
\hline
\end{tabular}

Source: PLS Data Processing Results, 2021.

Based on the data in table 7 above, it can be seen that of the two hypotheses proposed in this study, all of them can be accepted because each of the effects shown has a P-Values $<0.05$. So it can be stated that the independent variable (the role of traditional markets) has a significant influence on the dependent variable (entrepreneurial interest and people's income).

The t-statistic value for the first hypothesis, namely the role of traditional markets on the interest in entrepreneurship, is 6.524 and the t-statistic value for the second hypothesis, namely the role of traditional markets in the community's economy, is 6329 . These results indicate that both hypotheses can be accepted because the t-statistic value of each variable is $>1.66$ (t-table).

Discussion of Hypothesis Test Results. Based on the results of data processing that has been carried out to answer the proposed hypothesis, it is known that both hypotheses are accepted. This shows that there is a significant influence between the independent variable (the role of traditional markets) and the dependent variable (entrepreneurial interest and people's income). The following is a discussion related to the analysis of the influence between variables in accordance with the proposed hypothesis.

The Role of Traditional Markets on Entrepreneurial Interests. The results of the hypothesis test show that the P-Values that form the influence of the role of traditional markets on the interest in entrepreneurship are 0.000 and the T-statistic is positive (6.524). These results indicate that the traditional market role variable has a positive effect on entrepreneurial interest. This means that the role of traditional markets can trigger the interest of the surrounding community to take part in conducting transactions or starting a business. During a pandemic like this, most shops and malls are closed so that transaction activities are more focused on traditional markets. Market activities that are always active are now starting to generate interest in the community to take part in starting a business and selling it to the market. In addition to selling in the market, the community also makes purchases at traditional markets, especially the Badung market. 
The Role of Traditional Markets on People's Income. The results of the hypothesis test show that the P-Values that shape the influence of the role of traditional markets on the community's economy are 0.000 and the T-statistic value is positive (6.329). These results indicate that the traditional market's role variable has a positive effect on the community's economy, it means that with the existence of traditional markets in the area around the community financial turnover in the area around the market will be faster than in areas far from the market, so the average income of the community will be sufficient so that it can help the community's economic growth.

\section{CONCLUSION}

Currently the market has become an inherent part of social life; the market is used as a forum for entrepreneurship and increasing income. Some people even depend on the market for their daily work. The existence of the market is very vital for the community as well as for the economy of the surrounding community. The decline in tourism resulted in the community experiencing a fairly large impact, but seeing the traditional market still crowded so it was considered able to rotate the remaining money so that it fostered public interest in entrepreneurship. People started to open businesses in the market and around traditional markets to improve the current economy.

This study aims to determine the role of Traditional Markets (Badung Market) in Fostering Community Entrepreneurial Interest and improving the community's economy. This study uses 65 market participants and also the surrounding community. The results of this study indicate that there is a significant influence between the role of the traditional market (Badung Market) on the interest in entrepreneurship and people's income.

\section{REFERENCES}

1. Abdullah, Thamrin and Francis tantri. 2014. Marketing Management. Depok: PT Raja Grafindo Persada.

2. Andreas B. Eisingerich and Gaia Ruberu, "Drivers of Brand Commitment: A Cross National Investigation", Journal of International Marketing, Vol 18 No.2 (June, 2010), 27.

3. Boediono. 2015. Microeconomics. Yogyakarta: BPFE.

4. Ghozali, I. (2014). Structural Equation Modeling: Alternative Method with Partial Least Square (PLS). (4th Edition). Semarang: Diponegoro University Publishing Agency.

5. Hardianti. 2019. The Potential of Traditional Markets in Improving the Community Economy in Suli Market, Luwu Regency in the Perspective of Islamic Economics. Essay. Islamic Banking Study Program, Faculty of Economics and Islamic Business, State Islamic Institute (Iain) Palopo.

6. Putri, Amelia Permata., Yusri Abdilah. 2019. Analysis of Tourism Industry Development and Changes in Cultural Values in Ubud Village, Gianyar Regency. Journal of Administration and Business Vol. 68 No.1.

7. Slameto, (2015), Learning and Factors Affecting It, Revised Edition, 6th Printing, RinekaCipta Publisher, Jakarta.

8. Yamin, Sofyan and Kurniawan, Heri. 2011. New Generation Processing Research Data with Partial Least Square Path Modeling. Jakarta: Salemba Empat. 